\title{
Impact of Selenium-Supplemented Diets on Egg Morphometry and Quality in Four Varieties of Indigenous Aseel Chicken
}

\begin{tabular}{|c|c|}
\hline Khan MT' & (iD https://orcid.org/0000-0002-4734-3428 \\
\hline Rehman MS" & (iD) https://orcid.org/0000-0002-2259-9670 \\
\hline Abbas Ml" & (iD) https://orcid.org/0000-0002-1960-1776 \\
\hline Shafiq M" & (iD https://orcid.org/0000-0003-4847-5083 \\
\hline Akram MA" & (iD https://orcid.org/0000-0002-5762-8806 \\
\hline Rauf M"II & (iD) https://orcid.org/0000-0002-3269-2596 \\
\hline Gondal MA" & (iD https://orcid.org/0000-0002-7302-5829 \\
\hline Sharif $A^{\prime \prime}$ & (iD https://orcid.org/0000-0002-5362-3354 \\
\hline Raziq $\mathrm{F}^{\mathrm{V}}$ & (iD https://orcid.org/0000-0003-2021-4201 \\
\hline Bughio $\mathrm{E}^{\mathrm{V}}$ & (iD) https://orcid.org/0000-0002-1409-527X \\
\hline Liaqat SVII & (iD) https://orcid.org/0000-0001-6531-5124 \\
\hline Faroog Z ZuI & (iD) https://orcid.org/0000-0002-1956-8785 \\
\hline
\end{tabular}

Department of Poultry Science, Cholistan University of Veterinary and Animal Sciences, Bahawalpur-63100, Pakistan.

Livestock and Dairy Development Department, Poultry Research Institute, Rawalpindi-46300, Pakistan

III Department of Pathology, Cholistan University of Veterinary and Animal Sciences, Bahawalpur-63100, Pakistan.

iv Institute of Continuing Education and Extension, Cholistan University of Veterinary and Animal Sciences, Bahawalpur-63100, Pakistan.

Livestock and Dairy Development Department, KPK, Pakistan.

Department of Poultry Production, Shaheed Benazir Bhutto University of Veterinary and Animal Sciences, Sakrand-67210, Pakistan.

VII Faculty of Veterinary and Animal Sciences, The Islamia University of Bahawalpur-63100 Pakistan.

VIII Department of Zoology, Cholistan University of Veterinary and Animal Sciences, Bahawalpur-63100, Pakistan.

\section{-Mail Address}

Corresponding author e-mail address Dr. Muhammad Tahir Khan

Department of Poultry Science, Cholistan University of Veterinary and Animal

Sciences, Bahawalpur-63100, Pakistan.

Phone: +92-300-8360008.

Email: drmuhammadtahirkhan@cuvas. edu.pk

\section{- Keywords}

Aseel, egg morphometry, egg quality, selenium supplementation.

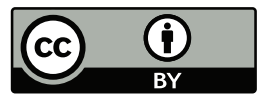

Submitted: 10/October/2020 Approved: 14/March/2021

\section{ABSTRACT}

The present study aimed at evaluating the effects of dietary selenium (Se) supplementation on egg morphometric and quality traits in Aseel chicken. In total, 84 adult molted Aseel hens, comprising 4 varieties (Lakha, Mushki, Peshawari, and Mianwali), were divided into 3 dietary treatments (organic at $0.30 \mathrm{ppm}$, inorganic at $0.30 \mathrm{ppm}$, and without selenium) with 7 replicates (1 bird in each) under randomized complete block design. Data were analyzed using factorial ANOVA and means were compared using Duncan's Multiple Range Test. The results indicated greater egg length in Mushki and Mianwali, lower egg breadth in Lakha, the highest $(p \leq 0.05)$ egg volume and surface area in Mianwali, and higher shape index in Lakha and Peshawari. Lakha had the highest Haugh unit and lower eggshell thickness with and without membrane than the other three varieties. Interaction of Se sources and Aseel varieties exhibited the highest $(p \leq 0.05)$ egg volume and surface area in Mianwali variety when fed on organic Se supplemented diet. Similarly, the interaction showed the highest eggshell thickness with membrane in Peshawari and without membrane in Mianwali when fed on inorganic Se supplemented diet. From the findings, it can be concluded that egg physical characteristics of Mianwali variety hens can be improved by the supplementation of Se-enriched yeast, as an organic Se source, in the diet.

\section{INTRODUCTION}

Egg morphometric parameters of the fertile eggs have gained a tremendous importance as they influence the hatching traits, including chick weight (Narushin et al., 2002; Narushin, 2005), egg hatchability (Narushin \& Romanov, 2002a; Narushin, 2005), eggshell quality (Narushin 2001b; Narushin, 2005), and egg interior quality (Narushin \& Romanov, 2002b; Narushin, 2005). The morphometric characteristics of the egg play an essential role in embryo development and successful hatching (Narushin \& Romanov, 2002). Various species of birds lay eggs with different shapes and sizes (Sekeroglu \& Altuntas, 2009), as different genetic groups (Nwachukwu et al., 2006; Yakubu et al., 2008) or Aseel varieties (Ahmad, 2013) stated to be responsible for changes in egg length and breadth. Furthermore, it is believed that shape index responds differently for different breeds (Ali et al., 2012), varieties (Ahmad, 2013), and strains (Anderson, 1996). Egg volume is another essential egg morphometric parameter described with discrepancies in values due to different Aseel varieties (Ahmad, 2013) and layer strains (Rayan et al., 2010). Egg surface area, likewise, also varies with the variations in genetic makeup (Anderson, 1996; Anderson et al., 2004; Ahmad, 2013). The internal quality of eggs is also vital for both table and hatching eggs (Sekeroglu \& Altuntas, 2009). Different breeds (Ali et al., 2012), varieties (Shafiq et al., 2013), 
and strains (Monira et al., 2003) of hens are among the significant factors that influence egg quality. The Aseel variety has heavy bodyweight (Ahmad et al., 2014) and strong muscular thighs (Dohner, 2001), can have the ability to withstand and survive in harsh tropical climatic conditions. Despite these excellent features, its potential regarding fertility and hatchability is not fully exploited because of poor egg physical characteristics and internal quality. Therefore, there is a dire need to improve the egg morphometric and quality traits of Aseel hens to achieve a reasonable progeny size. A balanced diet with dietary supplementation of selenium may improve egg morphometric and quality traits of Aseel eggs.

The appearance of compounds as nano-sized elements can result in unique properties, showing interactions with other ingredients, and change coordination with other compounds in biological systems, consistent with demonstration of compounds as larger elements or in solution (Gangadoo et al., 2020). Selenium is amongst the essential minerals compulsory for optimum development and production in birds. It maintains numerous functions linked to poultry rearing, production, and prophylaxis. Selenium is a fundamental portion of the enzyme glutathione peroxidase that works as an antioxidant enzyme and helps to govern levels of hydrogen peroxide and lipid peroxides (Ahmadi et al., 2018). Nowadays, selenium is known to modulate a wide spectrum of key biological processes and play a vital role in immune system functioning, protecting from oxidative injury, and carcinogenesis reticence as well. On the other hand, it is generally known that greater selenium quantities are dangerous causing several grave fitness complications (Ahmadi et al., 2019). The nanoselenium supplementation may improve feed intake, feed conversion, and weight gain in poultry. Moreover, nano-selenium stimulates immune system of broiler chickens in comparison with the other sources of selenium, as at nano-scales selenium shows novel and new potent properties. Consequently, supplementing poultry feed with nano-selenium is recommended to propagate poultry with enhanced performance (Shabani et al., 2019).

Dietary selenium (Se) is an essential trace mineral for poultry (NRC, 1994), identified to increase and maintain shell quality in older hens. Selenium, either inorganic as sodium selenite or organic such as selenocysteine, selenomethionine, and / or Se-enriched yeast (Foster \& Sumar, 1997) is reported to have a positive effect on various egg characteristics. Organic Se being more bio-available (Cruz \& Fernandez, 2011) has been preferred to improve shell quality and maintenance of egg freshness during storage (Papazyan et al., 2006). However, others still differ and state no difference in the performance of both organic and inorganic Se (Paton et al., 2000b). Very little work, so far, has been published on the evaluation of different egg physical and morphometric characteristics in Aseel chicken. Therefore, a study was designed to investigate the main and interactive effects of Se supplementation on egg morphometric and quality traits in different varieties of Aseel chicken. There is a hypothesis that dietary Se supplementation improves egg morphometric (egg length, breadth, volume, surface area, and shape index), and quality (egg weight, shell thickness, Haugh unit, and yolk index) characteristics in Aseel hens.

\section{MATERIALS AND METHODS}

\section{Experimental birds, housing, and ration}

The present study was conducted at the Indigenous Chicken Genetic Resource Centre (ICGRC), Department of Poultry Production, University of Veterinary and Animal Sciences (UVAS), Lahore, for eight weeks duration. The ethical committee of the University of Veterinary and Animal Sciences, Lahore, approved the protocol of the trial. In total, 84 adult females from four varieties of indigenous Aseel were used. From each array, 21 hens were further divided into three groups (7 each) according to the type of Se-supplemented diets in a Randomized Complete Block Design. Each of the seven hens was kept in an individual cage to get a separate record of egg production. The experiment was conducted in a well-ventilated open housing system. A corn-soybean meal basal diet was formulated for females keeping in view their nutritional requirement (NRC, 1994). The basal diet was iso-nitrogenous and iso-caloric containing 15.1\% CP and 2,682 ME Kcal/ $\mathrm{kg}$, respectively. Before the initiation of the trial, the basal diet was analyzed for Se content. The quantity of Se in the basal diet was $0.04 \mathrm{mg} / \mathrm{kg}$. Se from sodium selenite and Se-enriched yeast (Se-yeast Sel-plex® Alltech, Nicholasville, KY) was supplemented at 0.30 ppm into the basal diet. Control diet was without selenium supplementation (Table 1).

\section{Measurements}

In total, 84 eggs (21 from each variety), according to dietary Se treatments, were picked to study egg morphometric (egg length, egg breadth, shape index, egg surface area, and egg volume) and quality (egg weight, shell thickness with and without membrane, 
Khan MT, Rehman MS, Abbas MI Shafiq M, Akram MA, Rauf M, Gondal MA, Sharif A, Raziq F, Bughio E, Liaqat S, Farooq Z

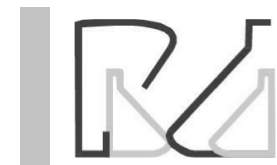

Impact of Selenium-Supplemented Diets on Egg Morphometry and Quality in Four Varieties of Indigenous Aseel Chicken
Table 1 - Ingredient and nutrient composition of basal diet.

\begin{tabular}{lc}
\hline Ingredients (\%) & Quantity \\
\hline Corn & 42.6 \\
\hline SBM $^{1}$ & 15.6 \\
\hline Corn Gluten (60\%) & 1.0 \\
Rice Tips & 19.0 \\
Wheat bran & 13.0 \\
DCP2 & 1.2 \\
CaCO & 7.4 \\
DL-Methionine & 0.2 \\
\hline Nutrient composition (\%) & \\
\hline CP & 15.1 \\
ME (kcal/kg) & 2682 \\
Calcium & 2.8 \\
Phosphorus & 0.4 \\
Lysine & 0.9 \\
Methionine & 0.5 \\
Selenium (mg/kg) & 0.04 \\
Vitamin premix ${ }^{3}$ & 0.20 \\
Mineral premix ${ }^{3}$ & 0.30 \\
\hline Soybean meal. &
\end{tabular}

'Soybean meal.

2Dicalcium Phosphate.

3Vitamin-mineral premix provided per kg of diet: Vitamin A (retinyl acetate), 12,000 IU; vitamin D3 (cholecalciferol), 5,000 IU; vitamin E (DL- $\alpha$-tocopheryl acetate), $50 \mathrm{mg}$; vitamin K3, 3 mg; thiamin, 2 mg; riboflavin, 7 mg; vitamin B6, 5 mg; vitamin B12, 15 $\mu \mathrm{g}$; pantothenic acid, $50 \mathrm{mg}$; folic acid, $1 \mathrm{mg}$; biotin, $200 \mu \mathrm{g}$; Fe, $80 \mathrm{mg}$; Cu, $10 \mathrm{mg}$; $\mathrm{Zn}, 80 \mathrm{mg}$; I, $1 \mathrm{mg}$.

Haugh unit, and yolk index) parameters. These eggs were weighed using electronic balance capable of measuring up to $0.1 \mathrm{~g}$. In contrast, egg length and breadth were measured with the help of a digital vernier caliper capable of measuring up to $0.1 \mathrm{~cm}$. The shape index was taken as the ratio between egg width and egg length (Anderson et al., 2004), whereas egg volume and egg surface area were determined using two separate formulae for each parameter and to take the average of the results (Etches, 1996). Eggs were then broken one by one, and the egg contents were carefully poured into a petri dish. Eggshell thickness was measured with and without vitelline membranes with the help of a dial pipe gauge and was taken as the average of three separate measurements from three different places without cracking the shell. Yolk index was chosen as the ratio between yolk height and yolk width whereas the Haugh unit score was measured using the egg weight and albumen height values in the formula $\mathrm{H}_{\text {unit }}=100 \times \log \left(\mathrm{H}+7.57-1.7 \times \mathrm{W}^{0.37}\right)$, where $\mathrm{H}=$ albumin height $(\mathrm{mm})$, and $\mathrm{W}=$ egg weight (g).

Data were analyzed using factorial ANOVA with the help of GLM procedure of Statistical Analysis System (SAS Institute Inc., 2002-04) and means were separated using Duncan's Multiple Range Test at 5\% probability level, considering each bird as an experimental unit.

\section{RESULTS AND DISCUSSION}

\section{Egg morphometric traits}

Mushki and Mianwali hens indicated significantly $(p \leq 0.05)$ greater egg length than those of Lakha and Peshawari (Table 2). This greater egg length may be due to variations in genotype and bodyweight as different strains, or varieties lay eggs of varying weight and size because of different bodyweights (Bell \& Weaver, 2005). Similarly, it was also observed that strains with varying bodyweight lay eggs of varying weight and size, which have their unique egg length (Arafa et al., 1982). Mianwali variety in interaction with inorganic Se supplemented diet revealed the highest egg length $(56.04 \pm 0.7)$ indicating synergistic effect.

Similarly, significant differences $(p \leq 0.05)$ were observed in egg breadth among varieties and their interaction with Se sources (Table 2). Birds of Lakha variety exhibited significantly lower $(p \leq 0.05)$ egg breadth than the rest of the three types, which may be due to genetic variations like different strains or varieties which lay eggs of varying egg weight and size (Bell \& Weaver, 2005). Similar results were reported in a study on strains of varying bodyweights, which lay eggs of varying egg weight and size, having their unique egg breadth (Arafa et al., 1982). A study conducted on Aseel, likewise, indicated maximum egg breadth in Mushki Aseel (Ahmad, 2013). Egg breadth was the highest when Mushki was fed diet supplemented with inorganic Se showing a positive relationship between Mushki and inorganic Se. However, the Se sources alone could not produce any effect on egg breadth.

Mianwali variety demonstrated the highest egg volume followed by Mushki, Peshawari, and Lakha (Table 2) that may be the result of more top egg length and breadth in several ranges. Another study on Aseel, however, indicated higher egg volume in Lakha and Mushki than than in the other two types (Ahmad, 2013). Brown breeder hens laid eggs of significantly higher egg volume as compared to those of white egg layers (Rayan et al., 2010). Interaction of organic Se and Aseel varieties resulted in the highest egg volume in Mianwali variety, which may be due to its trend and synergistic effect with organic Se. However, Se sources could not produce any effect on egg volume. Results indicated the highest egg surface area in Mianwali variety followed by Mushki, Peshawari, and Lakha (Table 2). This may be due to strain variation (Anderson, 1996; Anderson et al., 2004) and comparatively higher egg length and breadth in that variety. Significant differences in egg surface area, likewise, have already 
Table 2 - Effects of dietary selenium supplementation on egg morphometric traits in four varieties of Aseel chicken.

\begin{tabular}{|c|c|c|c|c|c|c|}
\hline \multicolumn{2}{|c|}{$\begin{array}{l}\text { Parameters } \\
\text { Variables }\end{array}$} & $\begin{array}{l}\text { Egg Length } \\
(\mathrm{mm})\end{array}$ & $\begin{array}{l}\text { Egg Breadth } \\
(\mathrm{mm})\end{array}$ & $\begin{array}{l}\text { Egg Volume } \\
\left(\mathrm{mm}^{3}\right)\end{array}$ & $\begin{array}{c}\text { Surface Area } \\
\left(\mathrm{mm}^{2}\right)\end{array}$ & Shape Index \\
\hline \multicolumn{7}{|c|}{ Se Sources } \\
\hline \multicolumn{2}{|c|}{ Organic Se } & $52.54 \pm 0.9$ & $40.25 \pm 0.4$ & $44.36 \pm 1.6$ & $61.38 \pm 1.5$ & $76.81 \pm 1.2$ \\
\hline \multicolumn{2}{|c|}{ Inorganic Se } & $51.75 \pm 1.4$ & $40.47 \pm 0.7$ & $45.27 \pm 1.9$ & $62.17 \pm 1.8$ & $78.52 \pm 1.2$ \\
\hline \multicolumn{2}{|c|}{ Control } & $51.79 \pm 0.8$ & $40.25 \pm 0.4$ & $43.22 \pm 1.16$ & $60.36 \pm 1.1$ & $77.83 \pm 0.8$ \\
\hline \multicolumn{7}{|c|}{ Varieties } \\
\hline \multicolumn{2}{|c|}{ Lakha } & $49.08 \pm 1.6^{b}$ & $38.99 \pm 0.8^{b}$ & $38.75 \pm 1.6^{d}$ & $56.07 \pm 1.5^{d}$ & $79.73 \pm 1.1^{\mathrm{a}}$ \\
\hline \multicolumn{2}{|c|}{ Mushki } & $53.84 \pm 0.6^{a}$ & $40.66 \pm 0.5^{a}$ & $45.75 \pm 1.3^{b}$ & $62.72 \pm 1.2^{\mathrm{b}}$ & $75.55 \pm 0.7^{b}$ \\
\hline \multicolumn{2}{|c|}{ Peshawari } & $50.71 \pm 0.9^{b}$ & $40.27 \pm 0.5^{a}$ & $42.81 \pm 1.1^{c}$ & $59.99 \pm 1.0^{c}$ & $79.57 \pm 1.4^{a}$ \\
\hline \multicolumn{2}{|c|}{ Mianwali } & $54.49 \pm 0.7^{\mathrm{a}}$ & $41.37 \pm 0.4^{\mathrm{a}}$ & $49.81 \pm 0.9^{a}$ & $66.42 \pm 0.8^{\mathrm{a}}$ & $76.03 \pm 1.2^{b}$ \\
\hline \multicolumn{7}{|c|}{ Se Sources $\times$ Varieties } \\
\hline \multirow{4}{*}{ 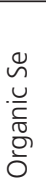 } & Lakha & $52.82 \pm 2.6^{\mathrm{abc}}$ & $40.95 \pm 1.0^{\mathrm{ab}}$ & $42.61 \pm 3.2^{\mathrm{dc}}$ & $59.76 \pm 3.1^{d c}$ & $77.73 \pm 2.0^{\mathrm{ab}}$ \\
\hline & Mushki & $53.85 \pm 0.9^{a b c}$ & $39.68 \pm 0.3^{b}$ & $43.52 \pm 0.8^{\mathrm{dc}}$ & $60.69 \pm 0.7^{d c}$ & $73.73 \pm 1.4^{b}$ \\
\hline & Peshawari & $49.53 \pm 2.2^{c}$ & $39.23 \pm 0.2^{b}$ & $39.26 \pm 1.4^{\text {de }}$ & $56.63 \pm 1.3^{d}$ & $79.54 \pm 3.7^{\mathrm{ab}}$ \\
\hline & Mianwali & $53.97 \pm 0.2^{\mathrm{abc}}$ & $41.15 \pm 1.1^{\mathrm{ab}}$ & $52.04 \pm 1.0^{a}$ & $68.42 \pm 0.9^{a}$ & $76.23 \pm 1.9^{a b}$ \\
\hline \multirow{4}{*}{ 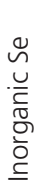 } & Lakha & $44.35 \pm 1.3^{d}$ & $36.65 \pm 0.9 c$ & $34.69 \pm 1.1^{e}$ & $52.14 \pm 1.1^{\mathrm{e}}$ & $82.74 \pm 0.8^{a}$ \\
\hline & Mushki & $54.93 \pm 0.5^{\mathrm{ab}}$ & $42.20 \pm 0.2^{\mathrm{a}}$ & $50.21 \pm 0.0^{a b}$ & $66.81 \pm 0.0^{\mathrm{ab}}$ & $76.83 \pm 0.8^{\mathrm{ab}}$ \\
\hline & Peshawari & $51.71 \pm 1.1^{\mathrm{abc}}$ & $41.52 \pm 0.4^{\mathrm{ab}}$ & $45.95 \pm 0.3^{\mathrm{bc}}$ & $62.95 \pm 0.3^{b c}$ & $80.39 \pm 2.5^{\mathrm{ab}}$ \\
\hline & Mianwali & $56.04 \pm 0.7^{a}$ & $41.51 \pm 0.7^{\mathrm{ab}}$ & $50.21 \pm 0.9^{a b}$ & $66.80 \pm 0.8^{\mathrm{ab}}$ & $74.10 \pm 1.8^{b}$ \\
\hline \multirow{4}{*}{ 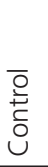 } & Lakha & $50.10 \pm 2.0^{b c}$ & $39.36 \pm 0.8^{b}$ & $38.95 \pm 2.1^{\text {de }}$ & $56.32 \pm 2.1^{\mathrm{de}}$ & $78.70 \pm 1.8^{\mathrm{ab}}$ \\
\hline & Mushki & $52.73 \pm 1.4^{\mathrm{abc}}$ & $40.11 \pm 0.8^{\mathrm{ab}}$ & $43.52 \pm 1.9^{d c}$ & $60.67 \pm 1.8^{d c}$ & $76.09 \pm 0.7^{\mathrm{ab}}$ \\
\hline & Peshawari & $50.88 \pm 1.5^{\mathrm{abc}}$ & $40.06 \pm 1.1^{\mathrm{ab}}$ & $43.21 \pm 1.1^{d c}$ & $60.40 \pm 1.0^{d c}$ & $78.78 \pm 1.5^{a b}$ \\
\hline & Mianwali & $53.45 \pm 1.9^{a b c}$ & $41.46 \pm 0.4^{\mathrm{ab}}$ & $47.17 \pm 1.7^{\mathrm{abc}}$ & $64.05 \pm 1.5^{\mathrm{abc}}$ & $77.75 \pm 2.5^{\mathrm{ab}}$ \\
\hline
\end{tabular}

Superscripts on different means within rows differ significantly $(p \leq 0.05)$.

been reported in Aseel varieties (Ahmad, 2013). The highest egg surface area was observed again in Mianwali variety when coupled with organic Se whereas Se sources alone could not show any effect on the egg surface area.

Among varieties, shape index was significantly higher $(p \leq 0.05)$ in Lakha and Peshawari type compared with Mushki and Mianwali (Table 2), which may be due to differences in genotype. In contrast, another study on indigenous Aseel reported a higher shape index in Mianwali and Peshawari than the rest of the two varieties (Ahmad, 2013). Different strains also have clear indications of having a significant effect on egg shape index (Anderson, 1996; Ali et al., 2012), resulting in higher egg shape index in brown layers than white egg layers (Brand et al., 2004; Rayan et al., 2010). The interaction of Se sources and varieties showed the highest shape index in Lakha when fed diet containing inorganic Se, which might be due to positive relationship between Lakha variety and inorganic Se. Different Se sources alone could not show any effect on shape index. Shape index, likewise, remained unchanged despite supplementation of Se in diet (Pavlovic et al., 2010), showing no response of sodium selenite or selenium-enriched yeast on shape index (Invernizzi et al., 2013). Organic Se in the form of
Sel-Plex ${ }^{\mathrm{TM}}$ also did not influence shape index (Renema, 2004; Hanafy et al., 2009).

\section{Egg quality traits}

Enhanced egg weight was observed in Mianwali variety followed by Mushki, Peshawari, and Lakha (Table 3), which might be due to higher bodyweight of the respective birds as speculated that bodyweight and egg weight are positively associated. Interaction of different treatments revealed that Mianwali variety produced eggs with an improved weight when diet was supplemented with organic Se, which might be attributed to Mianwali variety based on its higher bodyweight, further enhanced by supplementation of organic Se showing synergistic impact with Mianwali variety. However, Se sources alone could not exert any influence on egg weight. In a similar study on quail, no significant effect of different Se sources was reported on egg weight (Cruz \& Fernandez, 2011), which clearly showed that egg weight remained unchanged despite dietary supplementation of Se in the diet (Attia et al., 2010; Arpasova et al., 2012).

Significantly lower eggshell thickness ( $p \leq 0.05$; with and without membrane) was observed in birds of Lakha variety in comparison to the other three types (Table 3), which might be due to genetic variations. 
Table 3 - Effects of dietary selenium supplementation on egg quality traits in four varieties of Aseel chicken.

\begin{tabular}{|c|c|c|c|c|c|c|}
\hline \multicolumn{2}{|c|}{$\begin{array}{l}\text { Parameters } \\
\text { Variables }\end{array}$} & $\begin{array}{l}\text { Egg wt. } \\
\text { (g) }\end{array}$ & $\begin{array}{c}\text { Shell Thickness with } \\
\text { membrane }(\mathrm{mm})\end{array}$ & $\begin{array}{l}\text { Shell Thickness without } \\
\text { membrane }(\mathrm{mm})\end{array}$ & Haugh Unit & Yolk index \\
\hline \multicolumn{7}{|c|}{ Se Sources } \\
\hline \multicolumn{2}{|c|}{ Organic Se } & $48.58 \pm 1.8$ & $0.37 \pm 0.0$ & $0.35 \pm 0.0$ & $70.47 \pm 3.2$ & $0.49 \pm 0.0$ \\
\hline \multicolumn{2}{|c|}{ Inorganic Se } & $49.58 \pm 2.1$ & $0.37 \pm 0.0$ & $0.35 \pm 0.0$ & $73.16 \pm 2.1$ & $0.45 \pm 0.0$ \\
\hline \multicolumn{2}{|c|}{ Control } & $47.33 \pm 1.3$ & $0.37 \pm 0.0$ & $0.34 \pm 0.0$ & $72.96 \pm 1.9$ & $0.53 \pm 0.0$ \\
\hline \multicolumn{7}{|c|}{ Varieties } \\
\hline \multicolumn{2}{|c|}{ Lakha } & $42.44 \pm 1.8^{d}$ & $0.35 \pm 0.0^{b}$ & $0.31 \pm 0.0^{b}$ & $79.99 \pm 0.8^{a}$ & $0.52 \pm 0.1$ \\
\hline \multicolumn{2}{|c|}{ Mushki } & $50.11 \pm 1.4^{b}$ & $0.36 \pm 0.0^{\mathrm{ab}}$ & $0.35 \pm 0.0^{a}$ & $70.04 \pm 2.1^{b c}$ & $0.45 \pm 0.0$ \\
\hline \multicolumn{2}{|c|}{ Peshawari } & $46.89 \pm 1.2^{c}$ & $0.39 \pm 0.0^{a}$ & $0.35 \pm 0.0^{\mathrm{a}}$ & $74.52 \pm 2.1^{\text {ab }}$ & $0.52 \pm 0.0$ \\
\hline \multicolumn{2}{|c|}{ Mianwali } & $54.55 \pm 1.0^{\mathrm{a}}$ & $0.38 \pm 0.0^{\mathrm{ab}}$ & $0.36 \pm 0.0^{\mathrm{a}}$ & $64.23 \pm 2.8^{c}$ & $0.47 \pm 0.0$ \\
\hline \multicolumn{7}{|c|}{ Se Sources $\times$ Varieties } \\
\hline \multirow{4}{*}{ 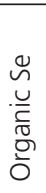 } & Lakha & $46.67 \pm 3.5^{\mathrm{dc}}$ & $0.36 \pm 0.0^{\mathrm{abc}}$ & $0.32 \pm 0.0^{\mathrm{bc}}$ & $81.04 \pm 1.1^{\mathrm{a}}$ & $0.49 \pm 0.0^{\mathrm{ab}}$ \\
\hline & Mushki & $47.67 \pm 0.9^{d c}$ & $0.37 \pm 0.0^{\mathrm{abc}}$ & $0.36 \pm 0.0^{\mathrm{ab}}$ & $72.42 \pm 4.8^{\mathrm{abc}}$ & $0.46 \pm 0.0^{a b}$ \\
\hline & Peshawari & $43.00 \pm 1.5^{\mathrm{de}}$ & $0.39 \pm 0.0^{\mathrm{abc}}$ & $0.36 \pm 0.0^{\mathrm{ab}}$ & $71.98 \pm 5.6^{\mathrm{abc}}$ & $0.55 \pm 0.1^{\mathrm{ab}}$ \\
\hline & Mianwali & $57.00 \pm 1.2^{\mathrm{a}}$ & $0.36 \pm 0.0^{\mathrm{abc}}$ & $0.35 \pm 0.0^{\mathrm{ab}}$ & $56.43 \pm 2.5^{d}$ & $0.45 \pm 0.0^{b}$ \\
\hline \multirow{4}{*}{ 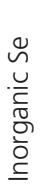 } & Lakha & $38.00 \pm 1.2^{\mathrm{e}}$ & $0.33 \pm 0.0^{c}$ & $0.28 \pm 0.0^{c}$ & $80.36 \pm 0.7^{a}$ & $0.43 \pm 0.0^{b}$ \\
\hline & Mushki & $55.00 \pm 0.0^{a b}$ & $0.34 \pm 0.0^{\mathrm{bc}}$ & $0.33 \pm 0.0^{\mathrm{abc}}$ & $69.83 \pm 3.3^{\mathrm{abc}}$ & $0.40 \pm 0.0^{b}$ \\
\hline & Peshawari & $50.33 \pm 0.3^{\text {bc }}$ & $0.41 \pm 0.0^{a}$ & $0.37 \pm 0.0^{\mathrm{ab}}$ & $76.64 \pm 2.0^{\mathrm{abc}}$ & $0.54 \pm 0.0^{\mathrm{ab}}$ \\
\hline & Mianwali & $55.00 \pm 1.0^{a b}$ & $0.40 \pm 0.0^{\mathrm{ab}}$ & $0.39 \pm 0.0^{a}$ & $65.79 \pm 4.4^{d c}$ & $0.45 \pm 0.0^{b}$ \\
\hline \multirow{4}{*}{ 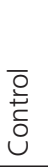 } & Lakha & $42.67 \pm 2.3^{\text {de }}$ & $0.37 \pm 0.0^{\mathrm{abc}}$ & $0.33 \pm 0.0^{\mathrm{abc}}$ & $78.57 \pm 2.2^{\mathrm{ab}}$ & $0.63 \pm 0.1^{a}$ \\
\hline & Mushki & $47.67 \pm 2.2^{d c}$ & $0.37 \pm 0.0^{\mathrm{abc}}$ & $0.35 \pm 0.0^{\mathrm{ab}}$ & $67.87 \pm 3.7^{b c}$ & $0.49 \pm 0.0^{\mathrm{ab}}$ \\
\hline & Peshawari & $47.33 \pm 1.2^{\mathrm{dc}}$ & $0.36 \pm 0.0^{\mathrm{abc}}$ & $0.33 \pm 0.0^{b c}$ & $74.92 \pm 3.2^{\mathrm{abc}}$ & $0.47 \pm 0.0^{\mathrm{ab}}$ \\
\hline & Mianwali & $51.67 \pm 1.8^{\mathrm{abc}}$ & $0.38 \pm 0.0^{\mathrm{abc}}$ & $0.35 \pm 0.0^{\mathrm{ab}}$ & $70.47 \pm 4.4^{\mathrm{abc}}$ & $0.52 \pm 0.0^{\mathrm{ab}}$ \\
\hline
\end{tabular}

Superscripts on different means within rows differ significantly $(p \leq 0.05)$.

Interaction of Se sources and types resulted in the lowest eggshell thickness with and without membrane in Lakha variety when fed with inorganic selenium supplemented diet. The Se sources, however, could not influence the eggshell thickness. Pavlovic et al. (2010) in laying hens and Cruz \& Fernandez (2011) in quail breeders as well, reported a similar response of Se on eggshell thickness, concluding that there is no difference between SS and SY groups for eggshell thickness (Invernizzi et al., 2013). The shell thickness, likewise, remained unaffected in layers when fed with organic selenium supplemented diet (Correia et al., 2000; Paton et al., 2000a).

Among varieties, the highest Haugh unit score was seen in Lakha, followed by Mushki, and then Mianwali (Table 3). It might be due to comparatively higher albumen height in that variety. A significant difference in Haugh unit score, likewise, was also found in a study on different breeds of poultry (Monira et al., 2003; Ali et al., 2012). Interaction of Se sources and varieties revealed maximum $(81.04 \pm 1.1)$ Haugh unit score in Lakha hens using the diet supplemented with organic Se, which might be attributed to the trend of Lakha variety for higher Haugh unit score. The Se sources alone, however, could not affect Haugh unit score. Likewise, Haugh unit score in layers was not changed even if the diet was supplemented with Se from an organic source (Correia et al., 2000) or regardless of the source (Patton, 2000; Cruz \& Fernandez, 2011). There is another claim that the administration of selenium (Mohiti-Asli et al., 2008), or organic trace minerals individually or in combination (Scatolini, 2007) did not affect Haugh unit score.

The highest yolk index was observed in Lakha when fed with a control diet. However, Se sources alone could not show any difference in yolk index (Table 3). Yolk index remained unaffected despite supplementation of Se in the diet (Mohiti-Asli et al., 2008; Attia et al., 2010; Cruz \& Fernandez, 2011) either in the form of organic or inorganic (Arpasova et al., 2012; Invernizzi et al., 2013). Varieties alone also could not show any difference in the yolk index. Non-significant differences ( $p>0.05)$ were reported in the yolk index among different types of Aseel (Shafiq et al., 2013; Ahmad, 2013), and between Vanaraja and White Leghorn breeds of chicken (Haunshi et al., 2011).

\section{CONCLUSIONS}

From the findings, it can expediently be concluded that Mianwali variety, for its good egg physical characteristics and positive interaction with the 


\section{Impact of Selenium-Supplemented Diets on Egg Morphometry and Quality in Four Varieties of Indigenous Aseel Chicken}

Bell DD, Weaver WD. Commercial chicken meat and egg production. 5th ed. New York: Springer Publishers; 2005

Brand HVD, Parameter HK, Kemp B. Effects of housing system (outdoor vs cages) and age of laying hens on egg characteristics. British Poultry Science 2004;45(6):745-52

Correia GMG, Takata FN, Medeiros JP, Barros ACS, Aguiar JFC, Evencio Neto J. Efeito do tempo de armazenamento sobre a qualidade de ovos de aves tratadas com selenio organico. Revista Brasileira de Zootecnia 2000;29(5):1440-1445

Cruz VC, Fernandez IB. Effect of organic selenium and zinc on the performance and egg quality of Japanese quails. Brazilian Journal of Poultry Science 2011;13(2):91-95.

Dohner JW. The Encyclopedia of historic and endangered livestock and poultry breeds [Yale agrarian studies series]. London: Yale University Press; 2001. p. 425-427

Etches RJ. Reproduction in Poultry. Wellingford: CAB International; 1996.

Foster LH, Sumar S. Selenium in health and disease: A review. Critical Reviews in Food Science and Nutrition 1997;37(Suppl. 3):211-228.

Gangadoo S, Dinev I, Willson NL, Moore RJ, Chapman J, Stanley D. Nanoparticles of selenium as high bioavailable and non-toxic supplement alternatives for broiler chickens. Environmental Science and Pollution Research 2020;1-8.

Hanafy MM, El-Sheikh AMH, Abdalla EA. The effect of organic selenium supplementation on productive and physiological performance in a local strain of chicken.1-The effect of organic selenium (Sel-Plex ${ }^{\mathrm{TM}}$ ) on productive, reproductive and physiological traits of Bandarah local strain. Egyptian Poultry Science 2009;29(IV):1061-1084.

Haunshi S, Niranjan M, Shanmugan M, Paddhi MK, Reddy MR, Sunitha $R$, et al. Characterization of two Indian native chicken breeds for production, egg and semen quality, and welfare traits. Poultry Science 2011;90(2):314-320.

Invernizzi G, Agazzi A, Ferroni M, Rebucci R, Fanelli A, Baldi A, et al. Effects of inclusion of selenium-enriched yeast in the diet of laying hens on performance, eggshell quality and selenium tissue deposition. Italian Journal of Animal Science 2013;12(1):1-8.

Mohiti-Asli M, Shariatmadari F, Lotfollahian H, Mazuji MT. Effects of supplementing layer hen diets with selenium and vitamin $\mathrm{E}$ on egg quality, lipid oxidation and fatty acid composition during storage. Canadian Journal of Animal Science 2008;88(3):475-483.

Monira KN, Salahuddin M, Miah G. Effect of breed and holding period on egg quality characters of chicken. International Journal of Poultry Science 2003;2(4):261-263.

Narushin VG. Egg geometry calculations using measurements of length and breadth. Poultry Science 2005;84(3):482-484.

Narushin VG. What egg parameters predict best its shell strength? Proceedings of $9^{\text {th }}$ European Symposium on the Quality of Eggs and Egg Products; 2001; Kusadasi, Turkey. p.349-355.

Narushin VG, Romanov MN. Egg physical characteristics and hatchability. World's Poultry Science Journal 2002b;58(3):297-303.

Narushin VG, Romanov MN. Physical characteristics of chicken eggs in relation to their hatchability and chick weight [paper 026066]. St. Joseph: American Society of Agricultural and Biological Engineers; 2002a

Narushin VG, Romanov MN, Bogatyr VP. Relationship between preincubation egg parameters and chick weight after hatching in layer breeds. BioSystems Engineering 2002;83(3):373-381 
Khan MT, Rehman MS, Abbas MI, Shafiq M, Akram MA, Rauf M, Gondal MA, Sharif A, Raziq F, Bughio E, Liaqat S, Farooq Z

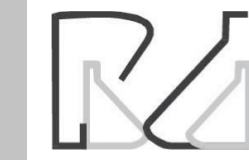

Impact of Selenium-Supplemented Diets on Egg Morphometry and Quality in Four Varieties of Indigenous Aseel Chicken
NRC - National Research Council. Nutrient requirements of poultry. $9^{\text {th }}$ ed. Washington: National Academy Press; 1994.

Nwachukwu EN, Ibe SN, Ejekwu K. Short term egg production and egg quality characteristics of main and reciprocal crossbred normal local, naked neck and frizzle chicken $\times$ exotic broiler breeder stock in a humid tropical environment. Journal of Animal and Veterinary Advances 2006:5(7):547-551.

Papazyan TT, Denev SA, Surai PF. Selenium in poultry nutrition: Lessons from research and wild nature. Krmiva 2006;48(5):275-283.

Parmar SNS, Thakur MS, Tomar SS, Pilla PVA. Evaluation of egg quality traits in indigenous Kadaknath breed of poultry. Livestock Research for Rural Development 2006;18(9): Article 132

Paton ND, Cantor AH, Pescatore AJ, Ford MJ, Smith CA. Effect of dietary selenium source and level of inclusion on selenium content of incubated eggs. Poultry Science 2000b;79(Suppl 1):40.

Paton ND, Cantor AH, Pescatore AJ, Ford MJ. Effect of dietary selenium source, level of inclusion and length of storage on internal quality and shell strength of eggs. Poultry Science 2000a;79(Suppl. 1):75

Patton ND. Organic selenium in the nutrition of laying hens: Effects on egg selenium content, egg quality and transfer to developing chick embryos [dissertation]. Lexington: University of Kentucky; 2000.

Pavlovic Z, Mileti I, Joki Z, Pavlovski Z, Skrbi Z, Sobaji S. The effect of level and source of dietary selenium supplementation on eggshell quality. Biological Trace Element Research 2010;133:197-202

Rayan GN, Galal A, Fathi MM, El-Attar AH. Impact of layer breeder flock age and strain on mechanical and ultra-structural properties of eggshell in chicken. International Journal of Poultry Science 2010;9(2):139-147.
Renema RA. Reproductive responses to Sel-Plex® organic selenium in male and female broiler breeders: impact on production traits and hatchability. In: Nutritional Biotechnology in the Feed and Food Industries. Proceedings of Alltech's 20th Annual Symposium; 2004 may 23-26; Nottingham: Nottingham University Press; 2004. p.81-91.

Scatolini AM. Mn, Zn e Se associados a moleculas organicas na alimentacao de galinhas poedeiras no segundo ciclo de producao [dissertação]. Jaboticabal (Sao Paulo): Faculdade de Ciências Agrárias e Veterinárias, Universidade Estadual Paulista; 2007

Sekeroglu A, Altuntas E. Effects of egg weight on egg quality characteristics Journal of the Science of Food and Agriculture. 2009;89(3):379-383.

Shabani R, Fakhraei J, Mansoori-Yarahmadi H, Seidavi A. Effect of different sources of selenium on performance and characteristics of immune system of broiler chickens. Brazilian Journal of Animal Science 2019;48: e20180256:1-9.

Shafiq M, Usman M, Ahmad Z, Akram M, Hussain J, Rehman A, et al. Pre and post-molt egg quality parameters as influenced by age in four varieties of Aseel chicken. Proceedings of the 33rd Pakistan Congress of Zoology, 2013; Islamabad (PAK): Pakistan Museum of History Natural; 2013. p.363.

Steel RGD, Torrie JH, Dickey DA. Principles and procedures of statistics. A biometric approach. New York: McGraw Hill Book Co; 1997.

Yakubu A, Ogah DM, Barde RE. Productivity and egg quality characteristics of free range Naked Neck and Normal Feathered Nigerian indigenous chicken. International Journal of Poultry Science 2008;7(6):579-585. 


\section{ERRATAS}

In the article Impact of Selenium-Supplemented Diets on Egg Morphometry and Quality in Four Varieties of Indigenous Aseel Chicken, Doi: 10.1590/1806-9061-2020-1277, published in the Revista Brasileira de Ciência Avícolas/Brazilian Journal of Poultry Science, v23 (2):001-008,

In page 01 where it was written:

$\begin{array}{ll}\text { Khan MT' } & \text { (D) https://orcid.org/0000-0002-4734-3428 } \\ \text { Rehman MS' } & \text { (D) https://orcid.org/0000-0002-2259-9670 } \\ \text { Abbas MI' } & \text { (D) https://orcid.org/0000-0002-1960-1776 } \\ \text { Shafiq M' } & \text { (D) https://orcid.org/0000-0003-4847-5083 } \\ \text { Akram MA' } & \text { (D) https://orcid.org/0000-0002-5762-8806 } \\ \text { Rauf M" } & \text { (D) https://orcid.org/0000-0002-3269-2596 } \\ \text { Gondal MA"II } & \text { (D) https://orcid.org/0000-0002-7302-5829 } \\ \text { Sharif A' } & \text { (iD https://orcid.org/0000-0002-5362-3354 }\end{array}$

Department of Poultry Science, Cholistan University of Veterinary and Animal Sciences, Bahawalpur-63100, Pakistan.

" Department of Pathology, Cholistan

University of Veterinary and Animal Sciences, Bahawalpur-63100, Pakistan.

III Institute of Continuing Education and Extension, Cholistan University of Veterinary and Animal Sciences, Bahawalpur-63100; tLivestock and Dairy Development Department, Poultry Research Institute, Rawalpindi-46300, Pakistan.
The correct form is:

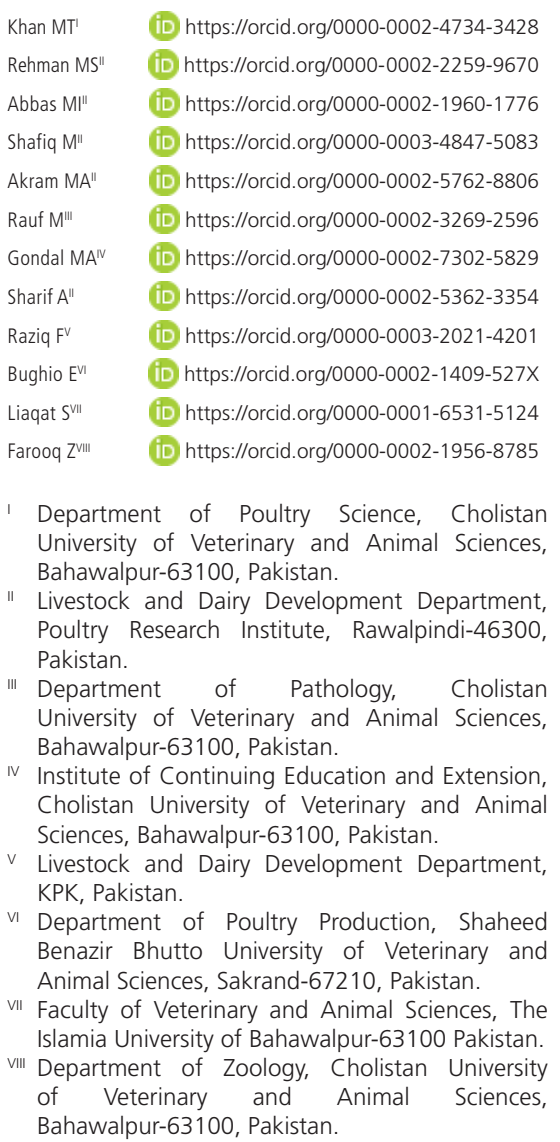

In page header 02 to 07 where it was written:

Khan MT, Rehman MS, Abbas M,

Shafiq M, Akram MA, Rauf M,

Gondal MA, Sharif A
The correct form is:

Khan MT, Rehman MS, Abbas MI,

Shafiq M, Akram MA, Rauf M,

Gondal MA, Sharif A, Raziq F,

Bughio E, Liaqat S, Farooq Z 